\title{
Democratic Security Sector Governance and Military Reform in Nigeria
}

\author{
E. Remi Aiyede \\ Senior Lecturer, Department of Political Science, \\ University of Ibadan, Nigeria
}

\begin{abstract}
Introduction
Nigeria began to reform its security sector as part of the transition from military to civilian rule at the start of the new millennium. The reforms began with an effort to convince the armed forces to return to their barracks and keep to their constitutional role as guardians of the state. Elections were conducted and a civilian administration took control of the government and military in a short transition programme organised by General Abdulsalami Abubakar's regime. The Obasanjo Government (1999-2007) implemented a series of reforms to strengthen political institutions after years of tyranny and economic recession. The National Economic Empowerment and Development Strategy focused on four main areas: improving the macroeconomic environment, pursuing structural reforms, strengthening the management of public expenditure, and implementing legal and statutory reforms. The Vision 20:2020 document became the blue print for the drive to make Nigeria the $20^{\text {th }}$ largest and most competitive economy in the world (NNPC 2009).

Although there were no explicit references to the reform of the security sector in these documents, the Obasanjo Government sought international assistance to support its military reform process. External agencies involved in the reform of the military included a private corporation, Military Professional Resources Incorporated (known commercially as MPRI), the American government's International Military Education and Training programme
\end{abstract}

How to cite this book chapter:

Aiyede, E R. 2015. Democratic Security Sector Governance and Military Reform in Nigeria. In: Bryden, A and Chappuis, F (eds.) Learning from West African Experiences in Security Sector Governance, Pp. 97-116. London: Ubiquity Press. DOI: http://dx.doi.org/10.5334/bau.f. License: CC-BY 4.0. 
and the British Defence Advisory Team. As Nigeria continues to face severe security situations, reforming the security sector has remained on the political agenda through successive governments, not least because the legacy of the country's extended military rule post-independence has inflicted great damage on the psyche of both civilians and the military itself (Siollun 2013).

Key reform issues include the prevention of coups, the demilitarisation of society, the subordination of the military to civilian control, the use of the military for policing functions, the need to decentralise the police, the need to build the capacity of the military to combat insurgency, and prison and criminal justice system reform. These elements of security sector reform have become a major on-going feature of public discourse in the media. The recent engagement of the military with the fight against terrorism, especially the Boko Haram insurgency, has brought these issues to the fore across Nigerian society, not least because the controversies that have surrounded the faltering and protracted engagement of the military with Boko Haram has raised issues about the military's readiness and capability.

In 2014 Governor Kashim Shettima claimed that Nigeria's soldiers were poorly armed and ill motivated, making the debates all the more urgent (Onuoh 2014). $\mathrm{He}$ also spoke of cases of desertion, soldiers' wives publically demonstrating against their husbands' deployment without proper equipment, recurring cases of corruption within the military and reports of soldiers shooting commanding officers for orders leading to fatalities. In a context where a military transformation programme is supposed to be in place and there are increasing demands on the military to aid civil authority (accompanied by a concurrent increase in the budget for the defence sector), the call for engagement on the issue became more urgent across the country and even around the world (BBC 2015).

What has happened to the effort to reform the military in Nigeria? What trajectory has it taken? Has the reform of the military stalled or was it wrong headed from the start? Which actors have been involved and what roles have they played? How can the reform be revived and redirected to address contemporary security challenges? This study explores the answers to these questions and demonstrates that Nigeria lost several opportunities to transform its military into an effective and efficient force capable of deterring external aggression and maintaining internal security within the framework of democratic civilian control.

Critically, General Obasanjo's move to alter the constitution to provide for a third term for the president and state governors slowed down his government's commitment to military reform. This provided space for the military to take control of the defence sector reform from civilian authorities; thus, the reform became coloured by the preferences of the emergent military leaders, their failures to address structural defects in the management of the military due to self-interest and frequent changes in the military's leadership: this, in turn, derailed the implementation of a systematic transformation of the milit- 
ary. Other structural factors that have affected the reform process include the ill-health and eventual death of President Yar' Adua, who succeeded President Olusegun Obasanjo, and the emergence of Boko Haram as a major security threat. Under President Goodluck Jonathan, the military's counter-terrorism engagement with Boko Haram not only affected the trajectory of military reform, but also revealed the limitations and failures of reform efforts to date and underlined inter-agency rivalry, especially with the police. Reform efforts had failed so drastically that the 2014 Minister of Defence, Senator Musiliu Obanikoro, talked about a fresh move to reform the military (Eghaghe 2014: 1).

This paper argues that Nigeria lost several opportunities to transform its military into an effective and efficient force capable of deterring external aggression and maintaining internal security within the framework of democratic civilian control. It argues further that the trajectory of democratic politics as shown in the move by General Obasanjo to alter the constitution in order to provide for a third term for presidents and state governors slowed down the commitment to military reform by the Obasanjo government. This provided the space for the military to take control of the reform of the defence sector from the civilian authorities, derailing the implementation of a systematic transformation of the military. The argument begins with an overview of the development of the military since the colonial era; it also explores the series of post-independence efforts to develop the military into a reliable institution for the defence and security of the country. It outlines the broad context of military reform under Obasanjo from 1999 to 2007, when the country returned to civilian rule after over two decades of military dictatorships. The paper then examines in detail the counter-programme of transformation instituted by the military, its level of implementation and the key factors behind the current state of military reform. Finally, the paper proposes a way forwards based on the requirements for systematic transformation that have remained unaddressed.

\section{Context for Security Sector Governance in Nigeria}

Nigeria became independent of British colonial rule on 1 October 1960. Thereafter Nigeria operated a parliamentary system of government as a federation of three regions (Northern, Eastern and Western). In 1963, it became a republic. The same year, a fourth region was created: the Midwestern region.

The Federal Defence Council was established in 1957: it comprised representatives of federal and regional governments and the governor general chaired it. The Federal Defence Council made the first set of formal defence-policy decisions and determined the structure of the Nigerian army, including its recruitment criteria and the nature of the parliamentary procedures to determine and approve its annual budget. The Federal Defence Council became fully 
responsible for the Nigerian army in the immediate post-independence era, completing the Nigerianisation of the army in 1960, even though a large proportion of British officers continued to serve in the highest ranks. At this time, civil society and the media were heavily involved in security policy, as seen in the demonstrations that greeted the proposed Anglo-Nigerian Defence Pact and Nigeria's continued participation in the international peace-support operation in the Congo after the execution of Patrice Lumumba. Meanwhile, parliament played a role in the introduction of a quota in officer recruitment policy to reflect the diversity of the country (Alaga \& Akum 2013).

However, progress in defence reform was halted when the First Republic came to an abrupt end on 15 January 1966 in a coup détat. This coup was the ultimate result of the governance crisis that characterised the First Republic's brief rule: key issues included the muted confrontation between the president and the prime minister arising from the 1964 federal elections and the rigged Western regional elections of 1965 that resulted in the breakdown of law and order in the region. The coup was largely viewed as a sectarian Igbo coup because almost all of the First Republic politicians and military leaders killed, with the exception of one Igbo officer, were from the north or south west.

The country descended into civil war following a counter-coup on 29 July 1966, which was viewed as a revenge coup because apart from General Ironsi and Fajuyi, only one of the ten officers killed was not of Igbo extraction (Dudley 1973; Post \& Vickers 1973). With the counter-coup, the cohesion of the army under a single command was lost; the army command was disrupted when Lieutenant Colonel Ojukwu objected to the ascension of Lieutenant Colonel Gowon as head of state because he was not the next in command after General Ironsi. Although efforts were made to reconcile the parties, killings of Igbos in the Northern Region, and the subsequent declaration of the sovereign state of Biafra, heralded the beginning of a civil war that would last from 1967 until 1970. Thus on 27 May 1967 the Eastern Regional Consultative Assembly mandated Ojukwu to declare the independent Republic of Biafra: this was followed by the declaration of a state of emergency and the creation of a 12-state federal structure for governing Nigeria by General Yakubu Gowon (Osaghae 1998; Panter-Brick 1970). As a result of these political dynamics, the Igbo were marginalised in the military in the post-war period.

Another consequence of the civil war for the military was the increase in the size of the army: from about 7,000 personnel organised into only two infantry Brigades in 1967, the Army grew to over 250,000 officers and men in 1970 (Bali 1989: 164). Thus in the post war era, the effort to reduce the army into a more nimble force became a central element of the military reform and the transition from military rule to democracy. Although General Gowon promised a demobilisation of the army, little effort was invested in the exercise. Gowon was overthrown in 1975 for failing to keep faith with the transition programme intended to terminate military rule in 1976. General Murtala Mohammed, who 
became head of state after Gowon, planned to transition to a civil programme in 1979. He set up a constitution-drafting committee and restructured the country into 19 states. However, he was assassinated in an unsuccessful coup on 13 February 1976.

Following his assassination, General Murtala Mohammed was succeeded by General Olusegun Obasanjo, who carried on with the programme of transition to civil rule that ended in 1979 when the country returned to democracy with President Shehu Shagari as elected head of state. It is significant that only about 50,000 members of the armed forces had been demobilized at this point (Osaghae 1998: 82). Thus, in the post-civil war era the effort to reduce the armed forces became a central element of debates on military reform and the transition from military rule to democracy.

The 1979 Constitution outlawed coups and banned the military from partisan politics. It mandated the chief of defence staff to report directly to the president rather than the minister of defence, as was the case during the First Republic. Under the new system, legislative oversight was strengthened with committees for police, defence and intelligence affairs in both the House of Representatives and the Senate. However, having the chief of defence staff report directly to the president undermined the oversight functions of the legislature. Moreover, the military disregarded the new administrative tendering processes for contracts and also the legislative approval required for its expenditure. This was partly because the military commanders felt powerful enough to defy presidential orders. For example, Major General Dumuje ignored the orders of President Shagari over military action in aid of civil authorities during a religious insurgency in Kano. The military also tried to influence political appointments, including through sending "a list of their preferred candidates" for ministerial positions to the president in 1983, shortly before the coup of 31 December 1983 (Alaga \& Akum 2013: 221-222).

Despite these difficulties, the civil war and the immediate post-civil war years coincided with a double oil boom that enabled Nigeria to expand its Import Substitution Industries, invest in infrastructure, and finance massive imports of intermediate and capital goods, as well as raw materials and other consumer goods. Between 1975 and 1979 the economy grew by 8.3 per cent per year and Nigeria recorded a trade surplus of N2 billion in 1980, in spite of a sudden fall in oil prices in 1978 (Olukoshi 1993). The military expanded and acquired more modern equipment and artillery and also built barracks across the country. However, the development of urban roads and highways, and the introduction of social programmes, was accompanied by corruption involving military decision-makers and their bureaucratic aides. Although the Murtala Mohammed and Olusegun Obasanjo governments made efforts between 1975 and 1979 to establish budgetary mechanisms, many statutory institutions such as the military only used these processes when it suited them. Thus, as Omitoogun and Oduntan note, budgetary processes and expenditure were generally 
driven by the personality of the current head of state rather than by institutional mechanisms (Omitoogun \& Oduntan 2006: 158).

It was in this context that Nigeria's trade surplus turned into a deficit of 300 million by 1983 , with external debt at $\$ 21.38$ billion: a bewildering 989.2 per cent increase since 1980 (Adesina 1995: 18). Internal public debt rose from $\$ 4$.6 billion in 1979 to 22.2 billion in 1983, while national output fell by 8 per cent in 1982 and a further 5.5 per cent in 1984. Inflation, at 23 per cent in 1979, rose to 40 per cent in 1983 . To address the resultant sudden and severe payment crisis, Nigeria had to run large budget deficits and embarked on massive borrowing from private and official international sources to deliver on its financial programmes. In the process the country amassed huge debts. In an attempt to stem the crisis, the Shagari administration promulgated an Economic Stabilization (Temporary Provisions) Act in April 1982, in addition to attempting various austerity measures to reduce government expenditure and curtail imports. These measures were reinforced by the Buhari government, which had overthrown the Shagari government in a military coup d'état in 1983.

When Ibrahim Babangida took over from Buhari in 1985, he instituted an economic-reform programme alongside a transition back to democracy programme. However, under his rule power was concentrated in the presidency. To garner support for his government, he used promotions, redeployment, the appointment of military officers to political positions, and preferential treatment regarding the award of contracts for retired officers, in addition to buying cars for officers in certain ranks. At other times, he tried to incite members of the armed forces against civil society during public protests against his government, describing these protests as attempts to "destroy the credibility of the military" or "humiliate the military out of office", declaring that "it is only the military that can lead the armed forces back to the barracks" (Adekanye 1997: 45, 47).

Despite these problems, under Babangida's administration the lot of the Igbos in the military gradually began to improve for the first time since the civil war when Ebitu Ukiwe, an Igbo, was briefly appointed chief of general staff. However, the question of regional balance has remained a major challenge in Nigeria, in spite of subjecting the enlistment of candidates into the military and other statutory services to the federal character principle - a provision in the 1979 Constitution requiring public appointments fairly reflect the linguistic, ethnic, religious, and geographic diversity of the country.

Babangida's annulment of the 12 June 1993 presidential elections, which was supposed to conclude the protracted transition programme to civilian rule, catalysed a major political crisis, provoking civil discontent, deepening divisions among the various ethno-linguistic groups and generating calls for the reconstruction or reform of the military. As a result, Babangida stepped aside, leaving an interim government to conclude the transition to civil rule. However, the interim government was declared illegal by a court of law: General Sani Abacha removed it from power later in 1993 in a bloodless coup. Abacha 
demolished all existing democratic structures and began a fresh attempt to transition to democratic rule with a programme designed to transform him into a civilian president. However, he died suddenly on 8 June 1998. His death provided a window for democratic and military reform. Abacha's successor, General Abdulsalami Abubakar, began a campaign to encourage the military to return to their barracks by 29 May 1999 .

General Abdulsalami Abubakar's government commenced their attempt to reform the military with a 10 -month transition-to-civil-rule programme. The major plank of this reform was Abubakar's plan to persuade the military to return to barracks. He also took steps to improve their welfare, increasing salaries for both enlisted ranks and officers by the end of 1998. He set up a committee that organised a series of workshops for the armed forces and the police on welfare, re-professionalisation and the need to return to democracy. He also eased the political atmosphere by releasing political opposition figures and civil society activists who had challenged the regime of General Sani Abacha. This was followed by a repeal of several decrees that legalised arbitrary arrest without trials and other restrictions on civil liberties. He also promised to look into cases of human rights abuses. He then began the process of producing a constitution for democratic rule.

The new constitution put the command chain and operational use of the military under the control of the president as civilian commander-in-chief, but with mandated oversight by the National Assembly. To a large extent this separated the military from direct involvement in the politics of the transition process, although the military continued to exert indirect influence over the choice of presidential candidates. However, beyond these basic measures no specific programme of long-term reform was introduced. Comprehensive reform of the security sector was therefore left to the incoming civilian administration.

\section{Democratisation of the Security Sector: 1999-2007}

In May 1999, Olusegun Obasanjo became president of a civilian administration known as the Fourth Republic. Five key issues ensured that military reform topped the new administration's agenda. The first factor concerned the need to address the Southern Region's claims about the dominance of the Northern Region, including the ethnic dominance of the Northern Region in the military. The second concerned the fear that military rule for 15 of the first 25 years of independence had led to the development of a culture of using coups to solve disagreements and that this would jeopardise future democratic rule. The third factor revolved around the need to reorganise the military to make it more compact and efficient, including by addressing corruption within the military to restore prudent and proper use of resources to increase the battle-readiness of its forces. The fourth issue concerned the need to develop an appropriate 
civil-military relationship that subordinated the military to civilian leadership and demilitarised Nigerian society by addressing its culture of violence, aversion to debate and the use of extreme measures in internal conflicts (Adejumobi 1999). The fifth factor comprised a number of related issues but centred on the need to depoliticise the military by removing soldiers from political office so that military service no longer conferred political power or extensive financial privilege; this was especially important in light of the tradition of cadets enlisting as a shortcut to political office. However, there was concern that soldiers exposed to the privileges, rapid promotions and stupendous wealth that political office could confer in Nigeria might no longer be content with the drab and unprestigious life of the barracks (Adekson 1979); thus, reform was needed to re-orientate the military to its primary function and encourage its officers to abstain from political power. A related issue was the need to re-professionalise the military in order to address the adverse effects of its politicisation on esprit de corps, respect for the military hierarchy and general discipline. The economic and political failures, and reoccurring coups and counter-coups under military rule have undermined claims by the military that they were on a corrective course; moreover, the rampant corruption that characterised military rule soiled the image of the military as a custodian of the unity and integrity of the Nigerian state.

Shortly after he assumed office in 1999, President Obasanjo retired over 100 generals and other officers in the middle ranks who had held political office. This strategic move purged the military of politicians in uniform and created space for a comprehensive reform process to commence. Thus the reform effort under the Obasanjo regime was informed by the desire to pre-empt any attempt by the Northern Region to use the military to re-establish political hegemony. Given the disproportionate number of officers from the Northern Region who had held political appointments under military rule, the move to re-professionalise the military through retiring these officers helped to improve the balance in regional representation across the higher military ranks. Following a review of the appointment of chiefs of defence staff and other services, new high-ranking officers from more diverse backgrounds were appointed to take the place of those who had been retired. The 2010 appointment of an Igbo, General Azubuike Ihejirika, as chief of army staff was celebrated in the media because he was the first Igbo officer to have occupied the post since the end of the civil war in 1970.

In his speech at the National War College (now the National Defence College) in 1999, he outlined the key elements of the proposed reform programme:

1. An elected civilian president as commander-in-chief of the armed forces, and the supremacy of elected state officials over appointed officers at all levels;

2. Civilian leadership of the ministry of defence and other strategic establishments; 
3. Decisions regarding the goals and conduct of military operations must serve the political and strategic goals established by the civil authority;

4. Application of civil principles to all military investigations and trials;

5. Right of Civil (Supreme Court) authority to review any actions or decision taken by the military judicial officers;

6. Other instruments for achieving supremacy of civil authority include constitutional clauses and legislative oversight functions (Manea \& Rüland 2013: 65).

Although Obasanjo later elaborated a series of reform programmes across a broad spectrum of governance, these often failed to include military reform. Indeed, both the National Economic Empowerment and Development Strategy and the Vision 20:2020 documents (NNPC 2004; 2009) articulated under Obasanjo administration ignored security sector governance and reform. Reviewing the content of, and effort behind, the reform of the security sector during this period, Manea and Rüland (2013: 64) observed both the absence of a comprehensive concept of reform and insufficient political will to ensure its implementation. The measures implemented by the Obasanjo administration to reform the military included the following:

1. The exercise of the power to appoint and remove service chiefs;

2. Making the Ministry of Defence a primarily civil body;

3. The institution of a Human Rights Violations Investigation Commission known as the "Oputa Panel" and a Human Rights Commission;

4. Reform of the military justice system by making all military court decisions subject to review of the Supreme Court;

5. Reform of civil-military relations (with MPRI);

6. Legislative oversight of the defence budget by requiring the National Assembly to scrutinise and pass the defence budget with oversight powers throughout the process;

7. The formulation of a National Defence Policy in 2006 (Nigeria 2006).

However, towards the end of the Obasanjo regime the pursuit of reform lost impetus due to the constant troubles between the president and the legislature, including controversy over President Obasanjo's effort to change the constitution to provide for a third presidential term. The president's pre-occupation with these political challenges distracted him from the reform effort, weakening the prospects for the National Assembly to enact both new legislation concerning the military and constitutional amendments to support military reform.

As Aiyede (2013: 177 - 179) and Manea and Rüland (2013: 64-69) note, the prospect of military reform was further undermined by the absence of widespread media and social support for democratic control of the military. Sev- 
eral opportunities for the reform of the military were wasted, including the possibilities offered by the recommendations arising from the Political Reform Conference of 2005. The Conference recommended a constitutional provision against coups amending section 1(2) of the 1999 Constitution, in addition to establishing the National Security Intelligence Council and the National Security Service Commission. Other recommendations included the political re-orientation of the military; retraining of the armed forces to encourage greater professionalism; the reorganisation of the defence industries corporation of Nigeria; investment in research and development focused on military applications, supported by committing at least five per cent of the defence budget to this work; the establishment of a Faculty of Technology at the National Defence Academy to support graduate/postgraduate studies in maritime/aeronautical engineering, armament technology and computer science; the establishment of a joint warfare school; improving welfare services for military personnel; and making the most of the military's engagement in peace-keeping operations. However, of the 116 constitutional amendments proposed, none was devoted to military issues. In the end this mattered little as the National Assembly's opposition to the proposal for a third presidential term resulted in them denying all the constitutional amendment proposals at that time.

The reform process also suffered from the resistance of the military to the use of foreign assistance, especially under Victor Malu, Chief of Staff from 1999 until 2001. However, President Obasanjo invited MPRI and the British Defence Advisory Team to support the reform programme. In response, some senior military officers argued that MPRI's knowledge about civilian-military relations, which was the focus of their intervention in Nigeria, was already taught at Nigerian military institutions. They further argued that the support offered regarding the re-professionaliation of the military was not based on any needs assessment or determined in consultation with the leaders of the military and, indeed, that it ran contrary to their expectations regarding external assistance. ${ }^{1}$

Under the Yar' Adua government that succeeded President Obasanjo in 2005, efforts by the civilian executive to pursue military reform were further stymied, despite security being one of the seven agenda items of the administration. This was largely because of the ill health and eventual death of the president, who was incapacitated for the better part of his 2007 - 2010 time in office. The presidency was run by his kitchen cabinet, a cabal that included his wife. When the president went to Saudi Arabia, he did not formally hand over power to the vice president, Goodluck Jonathan, for the duration of his trip, as stipulated by the constitution: instead, the Kitchen Cabinet kept the state of his health a secret. There was palpable fear that the military would take over in March 2010 when the president surreptitiously arrived back at Abuja Airport at night without informing the vice president, who eventually succeeded him later that year (Adeniyi 2011: 237). 
President Goodluck Jonathan went on to win the 2011 elections. However, the transformation agenda of his government did not include any significant move on the issue of military reform, despite the fact that the threat from Boko Haram intensified under his rule. There was high turnover in the leadership of the military, demonstrating civilian control over the appointment and retirement of the military leadership, but there was also a remarkable increase in the budget for defence. These decisions have been subject to parliamentary oversight. In the case of the appointment of service chiefs of the tri-services of the military, the President began to seek the confirmation of the Senate in 2013 after Justice Adamu Bello ruled on 1 July 2013 that the appointment of service chiefs was subject to confirmation by the Senate as noted earlier. Before them the president had removed and appointed the service chiefs without regard to parliament. The current practice is for the president to name the service chiefs and then refer the list to the Senate for confirmation. So far, none of those sent to parliament has been rejected.

\section{The Sustainability of Change}

In spite of the apparent slow-down in military reform, and the military's opposition to external involvement in this process, the military leadership has developed and implemented its own reform programme. However, the reform measures have depended on the priorities of each succeeding chief of army staff. For instance, in May 2004 the current chief, General Martin Luther Agwai, constituted a Change Management Committee with the responsibility to determine the structure, equipment and training needs of the Nigerian army to meet the threats and challenges for the next decade and beyond. A Framework for the Transformation of the Nigerian Army in the Next Decade (Volumes 1\& 2) was subsequently developed. The Office of Nigerian Army Transformation was established in 2006 to monitor and evaluate the transformation process, and to conceptualise, develop and ensure implementation of short, medium and longterm plans regarding the army's future.

In 2006, when Agwai became Chief of Defence Staff (CDS) he tried to extend these ideas to the other armed services. He set up the Armed Forces Transformation Committee within the Ministry of Defence to provide a guide for transforming the military as a whole. In 2008 the Committee produced a national military strategy document, two volumes of joint doctrine for the armed forces and a proposed structure for the higher management of defence (MOD 2008a; 2008b). These documents show that the Committee envisaged that military strategy would be revised every five years and the joint doctrine reviewed every two years. However, no revisions have occurred to date, nor was the planned management structure achieved. 
The Committee also published documents about its plans:

1. to restructure the Ministry of Defence for enhanced management of national defence;

2. to develop a National Military Strategy and Joint Operational Doctrine;

3. to provide ways and means of achieving highly professional and motivated human resources;

4. to establish joint acquisition and maintenance processes for both minor and major military hardware;

5. to set up a military Research and Development and Defence Industrial Base; and

6. to establish a credible military structure with the capabilities required to meet current and future challenges.

Of all these documents, the 2006 National Defence Policy was significant, not because it was produced with little or no input from parliament and civil society (Aiyede 2013: 176). Critically, the Policy adopted the joint-operation concept to enhance the operational efficiency of the military; however, the lack of centralised control made the practical application of the concept difficult. The structural issues that underlie this lack of centralisation are the result of ambiguities in the provisions of the Nigerian Armed Forces Act 2004, which assigned operational directives to the CDS, and section 217 of the 1999 Constitution, which was silent on the powers of the CDS as it related to the service chiefs, who take directives directly from the minister of defence or the commander-in-chief. This system effectively reduces the role of the CDS to that of an adviser to the commander-in-chief, who has operational command of the armed forces despite the CDS being theoretically responsible for the coordination and integration of the activities of the three armed services. A further complication is that the CDS is usually appointed from amongst the service chiefs and continues to serve in both capacities. This system recognises that effective and combat-efficient armed forces require that the CDS exercise operational control with powers to supervise, coordinate and determine the activities of the services. However, such powers would limit the president's influence over the leadership of the military: a system placing the president or the minister of defence in a position of power over the CDS and the three service chiefs provides a more robust opportunity for cultivating loyalty, dispensing rewards and exercising significant influence over the armed forces. Thus, these contradictions arose from the fact that the Nigerian Armed Forces Act 2004 was designed to preserve presidential control of the military's chain of command. The fact that service chiefs compete for audiences with the president and minister of defence has been perceived as a bulwark against coups or the possibility of the military speaking with a single strong voice to place demands on the political leadership. However, dispersing powers away from the CDS, 
especially regarding budgetary and operational issues, and instead giving them to individual services enables service chiefs to enjoy significant autonomy and budgetary powers: powers they are unwilling to relinquish. The practical result, as Menea and Ruland argue, is that "Purchase of military hardware are largely controlled by the service chiefs and to a lesser extent by the Chief of Defence Staff and the Defence Ministry" (Menea \& Rüland 2013: 73). There is also a tradition of the president financing military equipment through executive orders that allow access to extra-budgetary resources. Thus, both the presidency and the service chiefs are interested in maintaining the status quo.

The fact that the procurement process is often fraught with corruption made possible by these contradictions has seen them entrenched rather than addressed. ${ }^{2}$ However, as Oyegbile (2014) notes, a corruption-ridden procurement process accounts, at least in part, for the poor equipment holdings of the military and their weak morale. He quotes a retired senior military officer in demonstrating how unpopular this situation is amongst all but the highestranking officers:

"The war against terrorism or even a conventional war in this country cannot be won with the way things are going presently. Our system of military funding is fraught with corruption and open to clear abuse. Military budgets should never be given to military commanders or Chief of Army Staff as it is obtained presently." (Oyegbile 2014)

The joint doctrine contained in the 2006 National Defence Policy sought to emphasise the primacy of political leaders, elected officials and their appointed subordinates in establishing broad national policies and procedures in the defence sector, while ensuring that military officials rendered advice and recommendations on professional matters, including military capabilities, limitations and projections. The same policy also required military leaders to be responsive to public opinion by providing timely and accurate information to citizens in the course of their assigned missions and especially while employing force (MOD 2008b). While the military is best placed to offer timely, complete and accurate information on military matters so that the National Assembly can fulfil its constitutional responsibilities for military affairs effectively, civilian leaders chose not to fully implement the joint doctrine as envisaged. For instance, since 1996 civilian presidents have appointed and retired the top leadership of the armed services in line with the provisions of the constitution, but they have exercised these powers without due regard to the legislature, as required by law. Thus, Festus Keyamo, a human rights activist and lawyer, obtained a Federal High Court judgment in 2013 that challenged the practice of appointing service chiefs without the approval of the National Assembly. The court declared previous appointments null and void. This caused President Jonathan to formally seek confirmation from the Senate regarding appointments he made on 16 
January 2014: the Senate confirmed the new service chiefs on 29 January 2014 (Ojiabor 2014: 6). As a result of this case, the vigilance of civil society was able to use the court system to challenge abuse of processes by the executive, yet this remained an isolated victory.

Ultimately, in the post-Obasanjo period, the efforts invested in promoting the transformation programme within the military establishment foundered because of a lack of commitment. As a result, limited reform measures have been designed and implemented by the leaders of each service to serve their own interests. For instance, under Air Chief Marshal Paul Dike as CDS, several programmes, seminars, tours, conferences and workshops were held to explain and move the change process forward. The Transformation Office at the Defence Headquarters drew on the resources of independent think-tanks and private organisations to educate the military in an effort to improve its relations with the media and civil society (Onwudiwe \& Osaghae 2010). The three services also developed effective public relations directorates, while the army created a Wide Area Network Infrastructure to facilitate access to information to improve productivity, proficiency and operational effectiveness (Bojie 2011: 3).

Within the Nigerian army, sensitisation lectures, seminars, workshops and a revision of books and manuals were carried out to enhance the knowledge of personnel about the transformation process. These seminars and workshops were organised in Abuja and all divisional headquarters; they concerned issues such as civil-military cooperation, the Continental General Staff System and also attitude change. A new uniform was introduced to present a more friendly public face to society. Similarly, in 2011 General Onyeabor Azubuike Ihejirika, then chief of army staff, established the Department of Civil-Military Affairs to improve the image of the military, win public support and deal with matters relating to human rights, rule of law, and negotiations, liaison, and conflict management with the civilian populace (Alaga \& Akum 2013: 229).

Just as military reform finally seemed to be underway, Nigeria's security challenges began to deepen. Cases of kidnapping and robbery, as well as the rise in terrorism largely perpetrated by Boko Haram, led to a series of changes in the work of the security agencies. Virtually all security agencies are now involved in efforts to curb these problems. For instance, the military, the police and other security agencies have all established counter-terrorism units. Moreover, the military has been progressively engaged in key policing activities across 28 states of the country, meaning that it is often spread thin. The military's intervention in communal conflict zones, crime control and counter-terrorism have catalysed but also provoked controversies (Falana 2014). Crisis Group identifies three ways the Nigerian government has responded to the security challenges (ICG 2014); namely, budgetary increases, strengthening anti-terrorism legislation and boosting military capacity.

In the past few years, counter-terrorism efforts have been extended to cover the non-governmental security sector, including civil defence, private security 
companies, citizen-security agency collaborations and the justice system. The Terrorism (Prevention) Act was signed into law in 2011. This was followed by a 2012 amendment that designated the Office of the National Security Adviser as National Coordinator for Anti-Terrorism Efforts: a move intended to prevent in-fighting among security agencies over which should assume the lead in joint operations. The government also sought to improve training, personnel management, equipment (especially for close-quarters combat) and coordination. For example, over 7,000 security personnel from the military, police and Nigerian Security and Civil Defence Corps have been variously trained in urban warfare, counter-terrorism and counter-insurgency, intelligence and amphibious operations, demolition and explosive breaching, and tactical communication. The specialist military training institution, the Counter-Terrorism and Counter-Insurgency Centre in Jaji, Kaduna State, trained graduates from across the armed forces and the police.

However, Leren Blachard of the African Affairs Congressional Research Service observed that successive Nigerian governments have been slow in allowing the security services to participate in US training programmes; describing Nigeria as an "extremely challenging" partner to work with, she noted that Nigerian troops are "slow to adapt with new strategies, new doctrines and new tactics" (Akinloye 2014: 1). Nonetheless, in the wake of the Chibok kidnappings President Jonathan called for external support: China, America, Israel, France and the United Kingdom committed to providing assistance, and the California National guard is currently helping to establish the 143 Infantry Battalion - a force trained in special tactics for the express purpose of engaging Boko Haram in their rural strongholds (Iroegbu \&Adinoyi 2014: 1).

In response to persistent conflict in the Niger Delta and the wave of criminal activities (especially kidnappings) in South-East Nigeria, the president reestablished the Ahiara Barracks, which had been shut down in 1992 as part of the restructuring of the army. The facilities accommodate the newly created 14 Brigade with its garrison, a battalion and other supporting elements. A 145 Battalion has been proposed for Ikot Umoh Essien, Akwa-Ibom State; a 144 Battalion at Umuna, Rivers State; and an artillery regiment in Ebonyi State (Onuorah 2011: 4).

The government has increased the defence budget from $\$ 100$ billion (US\$625 million) in 2010 to $\$ 927$ billion (US\$6 billion) in 2011, and to $\$ 1$ trillion (\$6.25 billion) in 2012, 2013 and 2014. Although the defence sector took a third of the federal government's budget for 2014, in August 2014 President Jonathan presented a proposal for a loan of $\$ 1$ billion to the National Assembly to enable him to re-equip the military to fight insurgency and deal with other security challenges. Over 30 armored tanks and two helicopter gunships with in-built night vision technology were recently purchased and deployed to fight insurgency in the northeast, while the air force has taken delivery of six jets (McGregor 2015). 
Emergency rule was first declared in the three northeastern states on 13 May 2013 as a result of the intensity of Boko Haram's activities. Three extensions were routinely approved by parliament in its oversight capacity. On 17 November 2014, the National Defence Council decided that emergency rule in Adamawa, Yobe and Borno States be extended a fourth time; however, the House of Representatives turned down the request when it was presented for parliamentary approval. The Senate, which was divided on the matter, did not take any action until the emergency rule expired. The dominant view in parliament was that emergency rule had not made any difference to the counter-insurgency operations and that the president should resort to the provisions under the constitution and section 8 of the Armed Forces Act 2004 to empower himself to deploy the military to troubled parts of the country (Adejuwon 2014). Emergency rule was previously approved because the military had explained to parliament that it was necessary given the unpredictable situation and the threat to peace in the relevant part of the country, it would aid intelligence gathering and the operation against Boko Haram terrorists and provide legal backing for foreign military collaborators to enter Nigerian territory in aid of the counter terrorism operation.

Thus, the counter-terrorism effort has come to define current activities in the security sector, especially since the kidnapping of over 200 girls in Chibok in April 2014 and the subsequent escalation in the activities of Boko Haram. These events show the limitations and reversals that have occurred in the security sector reform programme. The counter terrorism effort has also attracted foreign interest and support, though partially through exposing the weaknesses of the military to the media and the public. Statements by interested foreign governments offering to work with the military have been damning regarding its capacity and preparedness. For instance Alice Friend, the Pentagon's Principal Director for African Affairs, stated that the "Nigerian military has the same challenges with corruption that every other institution in Nigeria does. Much of the funding that goes to the military is skimmed off the top" (Schmitt \& Knowlton 2014). Media reports on engagements with the insurgents generally agree that recent efforts at reform have proven at best ineffective and incomplete, while many positive developments have been reversed.

Corruption has been a particular concern of late. For instance, in 2014 Nossiter (2014) of the New York Times reported that foreign diplomats believe the Nigerian military has inadvertently hampered the hunt for the abducted girls of Chibok through their ineffectiveness and lack of capacity:

"the military is so poorly trained and armed, and so riddled with corruption, that not only is it incapable of finding the girls, it is also losing the broader fight against Boko Haram. The group has effective control of much of the northeast of the country, as troops withdraw from vulnerable targets to avoid a fight and stay out of the group's way, even as the militants slaughter civilians." (Nossiter 2014) 
The Nigerian media has made similar claims. Meanwhile, in February 2014, Kashim Shettima, Governor of Borno State, declared that Boko Haram fighters were better-armed and better motivated than government troops. In May 2014, soldiers of the main army units tackling Boko Haram, angry about deaths among their ranks following an ambush, opened fire on the car carrying their commanding officer, Major General Ahmadu Mohammed. Thus, controversy came to characterise military-media relations over the military's engagement with Boko Haram; there is a high level of distrust at least partially attributable to the military's poor public-information management.

The persistence and intensity of criticism regarding the military's failures in the war against Boko Haram led military spokesman Major General Chris Olukolade to appeal to the media to stop damping the morale of officers and men at the front (Agbambu 2014: 8). However, poor information management has led to wild speculation in the media about the possible complicity of some of its high-ranking officers in supporting Boko Haram with equipment and funds. For instance, Stephen Davies, the Australian who was appointed by the Nigerian government to help negotiate the release of the kidnapped schoolgirls, named a former chief of army staff as one of the sponsors of Boko Haram. There have also been claims that information provided by army officers has helped insurgents in ambushing military convoys (e.g. in the ambush that led to the May 2014 mutiny against Major General Ahmadu Mohammed) and in attacks on army barracks and outposts in Boko Haram's northeastern strongholds. In June 2014 several reports were published in the local media of senior officers under court martial for providing arms and information to Boko Haram extremists; in response the military confiscated newspapers from vendors to prevent them from circulating in nearby cities.

However, in August 2014 the media exploded with concerns about the strength and capability of the military when Boko Haram took over Gwoza, a small town in southern Borno: the insurgents hoisted a flag and declared a caliphate state. The inability of the military to root the insurgents out of the territory quickly, and the subsequent battle over Bama and Maiduguri, fueled further concern about the military's capabilities. The situation worsened when about 480 Nigerian soldiers made their way into Cameroon after a gruelling encounter with Boko Haram militants. The media reported this incident as desertion, while the military described the movement as a tactical manoeuvre (Onuorah 2014: 4; Akinlotan 2014: 80). Alongside these problems, the military has also come under severe criticism over its human rights record. For instance, Amnesty international have accused the Nigerian military of torture and extra-judicial killings in several recent reports (Amnesty International 2012 ; 2014).

It is in this context that media editorials have moved from advising the government to review its military strategy to calling for an overhaul. At the $58^{\text {th }}$ Nigerian Navy Week in May 2014, the defence minister, Senator Musiliu 
Obanikoro, approached President Jonathan with a proposal for a presidential retreat where stakeholders, the parliament, the private sector and other interested parties could meet to "develop a transformational roadmap for the Nigerian military" (Eghaghe 2014: 1).

\section{Conclusion}

President Olusegun Obasanjo's regime was the key actor in post-independence security sector reform, especially with regard to the military. Although Obasanjo's government set out a broad outline for reform, the process was largely centred on the executive without engaging significantly with the legislature and civil society; moreover, his drive to amend the constitution in order to provide for a third presidential term undid much of the good work and momentum that had been achieved, stalling efforts to amend legislation that would have encouraged further progress. After Obasanjo, the subsequent presidents, Yar' Adua and Jonathan, placed little emphasis on reforming the security sector, despite having to deal with severe security challenges. While they continued to exercise presidential powers over the appointment and retirement of the military's leadership, both largely left the armed forces to carry on with the process of reform in their own way. Thus, further reforms have reflected the preferences of the prevailing military leadership for more technical and effectiveness focused enhancements over substance democratic governance.

The reform agenda enjoyed significant momentum under Lieutenant General Martin Luther Agwai, who introduced the military transformation concept to the army during his time as chief of army staff, though he employed the term across all the forces when he became CDS. However, his successor, Lieutenant General Azazi, did not agree with this approach: indeed, as chief national adviser to the president he later stated that:

"the concept from the beginning has been that we should go beyond secrecy in security and accept public participation because at the end of the day, a security strategy should look at national objectives and how the nation could make progress without any hindrance." (Oloja \& Onuorah 2011: 1)

Military reform was revived when Air Chief Paul Dike became CDS, in a reform programme focused on improving civil-military relations through a community relations programme to expand, complement and strengthen existing public relations strategies. Reform has since stalled. Today, there are many unresolved issues, including new issues thrown up by the military's counter-insurgency efforts in the northeast. There are also disagreements among senior military officers not only about the best methods for achieving military 
reform, but the very content of military reform and transformation. Indeed, some officers take the view that reform efforts have been concluded and what is needed now is routine re-equipment and training to respond to new challenges. ${ }^{3}$ The fact that the military has been suspicious, cautious or even hostile to seeking external assistance regarding reform has further limited the degree of change achieved and sustained.

As Aiyede (2013: 176) and Manea and Rüland (2013: 67-69) note, since 1999 parliament has not been able to live up to the expectations generated by its extensive formal powers of law-making, including the creation of oversight powers regarding defence and security issues. This is partly because parliament lacks the required competence, political will and confidence to intervene in security issues. Thus, its role has been limited to defence oversight, including confirmation of new appointments to the position of CDS and approval of several requests by President Jonathan to extend emergency rule in the three northeastern states where the military is engage in counter-insurgency operations.

The media has started to cover security issues in greater detail, as the failures of the counter-insurgency activities against Boko Haram have demanded increasing public attention. However, there a sustained and detailed media and public debate about the security sector is yet to emerge in Nigeria. Civil society involvement in the military reform process is also relatively weak in Nigeria. Although a small number of organizations have been involved with police reform, there is an absence of specialist civil society expertise to promote democratic control of the military in the media, and civil society. This has translated into the weak contribution of the legislature, media and civil society and leaving the defence establishment to lead discussion. These absences have further contributed to the stagnation of the reform process.

Nevertheless, the military reform and transformation process has made modest achievements in the form of establishing civilian control of the armed forces and purging the military of those who held political office. However limited it remains, the parliamentary oversight exercised over defence affairs has increased. A systematic agenda for reform was worked out, notably under the auspices of the Office of Nigerian Army Transformation and later the Armed Forces Transformation Committee, involving how best to restructure the management of the military, revive discipline and esprit de corps, rejuvenate research and development, re-equip and train men and officers with appropriate skills. However, this agenda was not effectively or consistency pursued. This was due largely to a lack of will on the part of parliament as well as political and military leaders. It was further hampered by corruption and severe security challenges, including internal conflicts and terrorism.

In recent years, the Boko Haram terrorist challenge has become the key factor in determining the direction of change in the military's organisational structure. The Boko Haram counter-insurgency effort revealed the limitations of security sector reform in Nigeria and exposed the military's weakness to 
the public, especially with regard to the kidnapping of over 200 schoolgirls in Chibok at a time when that State was under emergency rule. Cases of mutiny, soldiers' disregard for orders, protest by soldiers' wives over the deployment of their husbands without adequate equipment and weapons support, the treachery of officers and claims of corruption have become a matter of major public concern, bringing the issue of security sector reform to the fore if not yet giving birth to a substantive public debate on the road ahead.

The main lesson to be learnt in and from Nigeria is that security sector reform must take into account the larger context of governance, especially the commitment of the political leadership, the interface between the military and civilian components of the Ministry of Defence, the interest and capacity of parliament and civil society to address security issues, and the general values that drive politics. The political enthusiasm for security reform that accompanied the democratisation process was lost early, while the initial promise of independence regarding ownership and continuity for the military could not be sustained. The changes in military operations and organisation provoked by its engagement with internal conflicts and counter-terrorism have translated into unsystematic changes in the military's operation and organisation. The 2008 reform documents must be reworked to take these changes into account if they are to be used to rejuvenate the military, re-structure the defence leadership in order to reap the benefit of the joint doctrine and inter-agency cooperation, and provide a framework for effective use of foreign assistance.

Nigeria's challenges include the need to develop sufficient capability, including adequate manpower, to deal with contemporary threats to security. It must also include reorganising the procurement process to ensure value for money, reduce corruption and improve the conditions of both lower ranking officers and men. The current engagement with Boko Haram and other terrorist groups means that it must also develop its intelligence network and capabilities to preempt and apprehend terrorists before they strike. Above all, reform must deal with broader issues concerning the renegotiation of power needed to build an inclusive system of governance with a strong parliament and civilian institutions, as well as media engagement to encourage debate through keeping the population informed so that they can make their views known. This, in turn, would strengthen the degree to which democratic principles are embedded in all aspects of Nigerian society - a critical pre-condition for security sector reform.

\section{Notes}

${ }^{1}$ Interview conducted by author 2014.

${ }^{2}$ Author's interview with military officers in February 2014.

${ }^{3}$ Discussion with military officers conducted by author in February 2014. 